\title{
Occurrence of the Indo-Pacific freshwater prawn Macrobrachium equidens Dana 1852 (Decapoda, Palaemonidae) on the coast of Brazilian Amazonia, with notes on its reproductive biology
}

\author{
CRISTIANA R. MACIEL, MANOEL L. QUADROS, FERNANDO ABRUNHOSA, \\ SANDRA BASTOS, HORACIO SCHNEIDER and IRACILDA SAMPAIO \\ Instituto de Estudos Costeiros, Universidade Federal do Pará, Campus de Bragança, \\ Alameda Leandro Ribeiro s/n, 68600-000 Bragança, PA, Brasil \\ Manuscript received on October 18, 2009; accepted for publication on August 16, 2010
}

\begin{abstract}
The freshwater prawn Macrobrachium equidens, which is native species of the Indo-Pacific Region, was recorded for the first time on the Amazon coast of Brazil. This species was found to inhabit the same environment as two native Macrobrachium species, M. amazonicum and M. acanthurus, and is morphologically very similar to the latter. The identification of the species was confirmed by the genetic analysis of sequences of the mitochondrial Cytochrome Oxidase (COI) gene. A detailed description of the morphological features and reproductive biology of M. equidens in this new environment is presented.
\end{abstract}

Key words: crustacean, Caeté Estuary, invasive species, mitochondrial COI gene, reproductive biology.

\section{INTRODUCTION}

Macrobrachium Bates, 1868 is represented by species inhabiting tropical and subtropical aquatic environments around the world (Holthuis 1952, Coelho and Ramos-Porto 1985, Bond-Buckup and Buckup 1989, Melo 2003). Approximately 210 species have been described (Short 2004). Eighteen species of Macrobrachium occur naturally in Brazil, where they are found in both freshwater habitats and costal areas (Ramos-Porto and Coelho 1990, Melo 2003, Magalhães et al. 2005).

Few studies are available on the diversity of the freshwater prawns of the Amazon basin. Ramos-Porto (1979), for example, described Pseudopalaemon amazonensis, a new species of the genus Pseudopalaemon Sollaud, 1911. Kensley and Walker (1982) reviewed the Amazonian palaemonids, and described two new species of Macrobrachium (M. ferreirai and M. inpa) and three of the genus Pseudopalaemon (P. chryseus, $P$. goudingi and $P$. nigramnis). In the Brazilian state

Correspondence to: Iracilda Sampaio

E-mail: ira@ufpa.br of Pará, eight native species of Macrobrachium and one exotic form (M. rosenbergii) have been recorded (Barros and Pimentel 2001).

In the present study, an investigation of the ecology of Macrobrachium species in the Caeté Estuary of eastern Brazilian Amazonia resulted in the collection of specimens that presented morphological features inconsistent with those of other species known from this region. The analysis of DNA sequences of the mitochondrial Cytochrome Oxidase I gene revealed that these specimens represent the species Macrobrachium equidens Dana 1852, which is native of the Indo-Pacific Region. This is the second exotic species of Macrobrachium to be found in the Brazilian Amazon, after the now widespread Macrobrachium rosenbergii De Man, 1879. Macrobrachium equidens is morphologically very similar to the native Macrobrachium acanthurus Wiegmann, 1836, with which it is easily confused. This paper presents a differential diagnosis of the morphology and reproductive biology of $M$. equidens in this new area of occurrence. 


\section{MATERIALS AND METHODS}

Collection of Specimens And Reproductive

Biology Data

Prawns were caught every month between October 2001 and September 2002 in the Taici Creek, a tidal channel that connects the Caeté and Taperaçu rivers, near the town of to Bragança city, located on the Amazon coast in the northeastern part of the Brazilian state of Pará $\left(00^{\circ} 58^{\prime} 22^{\prime \prime} \mathrm{S}, 46^{\circ} 44^{\prime} 37^{\prime \prime} \mathrm{W}\right.$ : Fig. 1). A standard monthly collection was conducted during the full moon period, when traps were set during the ebb tide and retrieved during the following daytime low tide. The standard sample consisted of ten prawn traps, known locally as matapis, baited with chicken entrails. When the traps were retrieved during the day, the temperature and $\mathrm{pH}$ of the water were measured with an Orion $\mathrm{pH}$ meter (accurate to 0.1), and salinity with an Atago refractometer (accurate to 0.5). A meteorological station located in the Caeté Estuary, approximately $20 \mathrm{~km}$ from the study site, supplied data on precipitation and atmospheric temperature.

The number of individuals collected was recorded, as were morphometric data, the frequency of ovigerous females, fertility, and fecundity. The weight of the specimens was recorded for the fresh body using digital scales (accurate to $0.1 \mathrm{~g}$ ). Total length (TL) was defined as the distance from the tip of the rostrum to the distal extremity of the telson. Lengths were measured using a digital caliper (accuracy $0.01 \mathrm{~mm}$ ). The results are given as mean \pm standard error. The sex of each individual was identified by the presence or absence of the masculine appendage on the second pair of pleopods. The size of the smallest male was used as the criterion for the identification of smaller, immature individuals.

The relative monthly frequency of egg-bearing females was analyzed for the definition of the reproductive period. Fecundity tests were recorded using thirty-two females (mean $\mathrm{TL}=57.80 \pm 6.09 \mathrm{~mm}$ ).

Ovigerous females were maintained in the laboratory for fertility analysis. Each female was kept in a $2.5 \mathrm{~L}$ recipient equipped with biological filters and constant aeration. After hatching, the larvae were counted under a stereomicroscope. The Spearman correlation coefficient was applied in order to evaluate the relationship between female size and number of larvae and eggs.

\section{DESCRIPTION AND DIAGNOSIS}

The terminology used in the description follows Holthuis (1951, 1952), Melo (2003) and Short (2004). Comparisons with other Macrobrachium species, including $M$. acanthurus, were based on the descriptions of these authors. Specimens of $M$. equidens were deposited in the Carcinology collection of the Emilio Goeldi Museum, Belém, Brazil (MPEG Lot 807: carapace $13,78 \mathrm{~mm} \pm 1,83, \mathrm{n}=10$ ovigerous female, Oct 2005, Taici creek; MPEG Lot 808: carapace 14,93 mm $\pm 1,69, \mathrm{n}=20$ non-ovigerous female, Aug 2005, Taici creek; MPEG Lot 809: carapace 14,02 $\mathrm{mm} \pm 3,14, \mathrm{n}=$ 13 adult male, Taici creek; collector Manoel Quadros). The specimens were examined in detail under a Zeiss (SV11) stereomicroscope, and illustrated with the help of a micrometric disk. Total length (TL) was defined as the distance from the tip of the rostrum to the distal extremity of the telson, and the carapace length (CL) as the one from the ocular margin to the posterior border of the carapace.

\section{Genetic AnALYSES}

The genetic analysis was carried out using six specimens of Macrobrachium sp., 12 M. acanthurus, six Macrobrachium amazonicum Heller, 1862 and one M. rosenbergii (exotic), all collected from the same locality. Total DNA was obtained from muscle tissue by the conventional phenol-chloroform protocol, and a fragment of COI was isolated via PCR using the following primers described by Palumbi and Benzie (1991): COIA: 5' - AGTATAAGCGTCTGGGTAGTC - 3' COIF: 5' - CCTGCAGGAGGAGGAGAYCC - 3'. The PCR reactions were conducted in $25 \mu \mathrm{l}$ using the following program in the thermocycler: 5 minutes at $94^{\circ} \mathrm{C}$ for initial denaturation, followed by 30 cycles of 30 seconds at $94^{\circ} \mathrm{C}$ (denaturation), 1 minute at $55^{\circ} \mathrm{C}$ (annealing) and 1 minute at $72^{\circ} \mathrm{C}$ (extension) and one final cycle of 7 minutes for extension was performed. The products were purified with the Exo-SapIT enzyme kit (GE Healthcare), and DNA sequences were generated in an ABI 377 automatic sequencer (Applied Biosystems).

The COI sequences were edited and aligned manually in the BioEdit program (Hall 1999). In order to verify the identification of the morphotype initially de- 


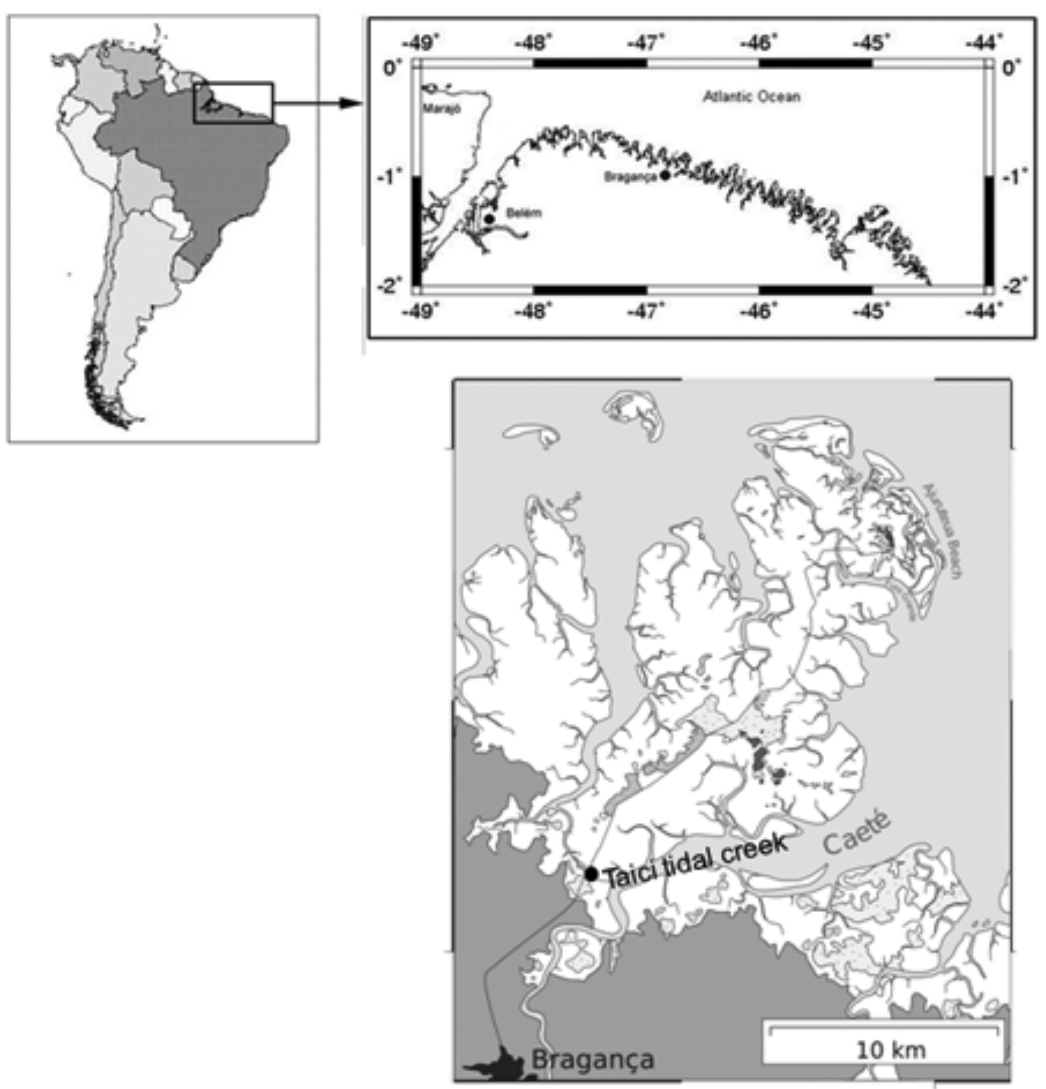

Fig. 1 - The Taici tidal creek, a channel of the Caeté Estuary in northeastern Pará, Brazil (Ulf Mehlig 2001).

nominated as Macrobrachium sp., the COI sequence of these specimens were compared against the Genbank via the Blast server. Surprisingly, these sequences were 97\% similar to those of Macrobrachium equidens from Taiwan (AB235250) and the Philippines (AB235248, both from Liu et al. 2007), thus confirming the occurrence of this Asian species on the Amazon coast. A COI data base was established with the newly-generated sequences from the Brazilian specimens together with some of the most similar sequences of Asian taxa such as $M$. equidens from Singapore (AB235249), $M$. latimanus from Taiwan (AB235278), M. maculatum from China (AB235280, from Liu et al. 2007), and also M. rosenbergii from Indonesia (AY659990, Miller et al. 2005) and Taiwan (AB235295, Liu et al. 2007). All newly-generated COI sequences were deposited in Genbank (accession codes JF737748-JF737758). To quantify the genetic differences, a nucleotide divergence matrix was obtained using the Kimura (1980) 81 model as suggested by Kakusan 2.0 (Tanabe 2007), and phylogenetic trees were generated in Mega 4.1 (Tamura et al. 2007) using 1000 bootstrap pseudoreplicates as the statistical support.

\section{RESULTS}

Genetic Identification Confirms the OcCurrence OF M. equidens IN BRAZIL

The alignment of the 416 base pairs revealed 11 distinct COI haplotypes in the four Macrobrachium species collected in the study area (Bragança, Brazil): one for $M$. rosenbergii, two for M. amazonicum, five for M. acanthurus and three for Macrobrachium sp. Nucleotide divergence among haplotypes was $0.5 \%$ in $M$. amazonicum, and varied from 0.2 to $0.7 \%$ in $M$. acanthurus and from 0.4 to $0.9 \%$ in Macrobrachium sp. Pairwise genetic divergence values varied from $14.8 \%$ in $M$. acanthurus vs. M. amazonicum to $21.7 \%$ in M. acanthurus vs. M. equidens. When these haplotypes were compared with the almost 300 ones available from Genbank, our 
Macrobrachium sp. diverged from $M$. equidens from Taiwan and the Philippines by only 3\% (Table I), which strongly suggests that this Brazilian morphotype is in fact $M$. equidens and not a native South American species as we previously have supposed.

South American and Asian and Indo Pacific $M$. equidens group together in the Neighbor-Joining tree with a bootstrap support of $100 \%$ (Fig. 2). All the other Macrobrachium species present similar high nucleotide divergences of around 20\% (Table I), and appear in the phylogenetic tree in polytomic and unresolved arrangements (Fig. 2), including M. equidens from Singapore, as already demonstrated by Liu et al. (2007).

\section{DiAgnosis AND DESCRIPTION OF THE BRAZILIAN Macrobrachium equidens}

\section{Diagnosis}

Rostrum elongate (Fig. 3a, b), curved slightly upwards, reaching or surpassing the distal extremity of the scaphocerite; superior margin with 9-12 teeth irregularly distributed, of which the proximal teeth are distributed almost uniformly (2-4 behind the orbit) and the distal teeth, more widely spaced in comparison with the others; inferior margin with 4-7 teeth. Antennal spine located below inferior orbital angle. Antennal spine smaller than hepatic spine. Carapace smooth. Second pereiopod (Fig. 3c, d) with merus longer than the anterior portion of the scaphocerite and numerous rows of longitudinal spines in all articulations; both fingers of the chelae covered by a pappose setal pubescence (Fig. 3c, d).

\section{Description}

Rostral formula: 2-4/9-12 (mode 11)/4-7 (mode 6). Abdomen smooth (Fig. 3a), posteroventral angle of the fifth abdominal segment sharp; sixth abdominal segment 1.6 times longer than the fifth segment. Telson (Fig. 3 e) with 2 pairs of dorsal spines; posterior margin with sharp median extremity and 2 pairs of lateral spines, the inner spines surpassing the median extremity; presence of numerous plumose setae (approximately 14) on the posterior margin, among the internal spines.

Basal segment of the antennular peduncle wide; stylocerite slightly sharpened, almost reaching half the length of the basal segment; anterolateral tooth reaching approximately the middle of the second segment, which is as long as the third segment. Scaphocerite 3.4 times longer than its width. Bilobed epistome with rounded lobes.

Mandibular palp three-segmented, incisive process distinctly separate from the molar process and disposed in different planes; incisive process with 3 sharp teeth; molar process more robust, bearing 4 blunt teeth. Maxillary palp bilobed, superior lobe narrow, inferior lobe robust. Maxilla with simple palp; basal endite bilobed; scaphognathite simple. First maxilliped with basal and coxal endites distinct; exopod with numerous setae distally, epipodite bilobed; second maxilliped with flagellum with numerous setae distally; third maxilliped with endopod robust; exopod with numerous setae distally.

First pereiopod narrower than the second, distal portion of the carpus longer than the scaphocerite; palm cylindrical, 1.3 times the dactyl length; carpus 3.7 times the palm length and 1.2 times longer than the merus. Second pereiopod with merus longer than the anterior portion of the scaphocerite and numerous rows of longitudinal spines in all articulations; both fingers of the chelae covered by a pappose setal pubescence; distal portion of the mobile finger of the chelae smooth, sharpened margin of the finger with 2 well-defined proximal teeth on the dactyl and one on the fixed finger, followed by 3 basal denticles; palm cylindrical slightly longer than fingers; carpus 1.5 times palm length and 1.7 times longer than the merus. Third pereiopod extends beyond the distal portion of the scaphocerite; propod with a longitudinal row of 6 spines on the inner margin, 3.5 times as long as the dactyl, twice the length of the carpus, but shorter than the merus. Fifth pereiopod extends beyond the distal extremity of the scaphocerite and bears a longitudinal row of 6 spines on the inner margin, almost 3.4 times as long as the dactyl and the merus, 1.6 times the length of the carpus. The last three pereiopods are covered completely with small setae. Male appendage twice as long as the inner appendage and bearing numerous, irregular setae.

\section{COLOR}

All specimens present a transparent body; however, the presence of chromatophores results in an appearance of reddish staining; the articulations of the second pair of 


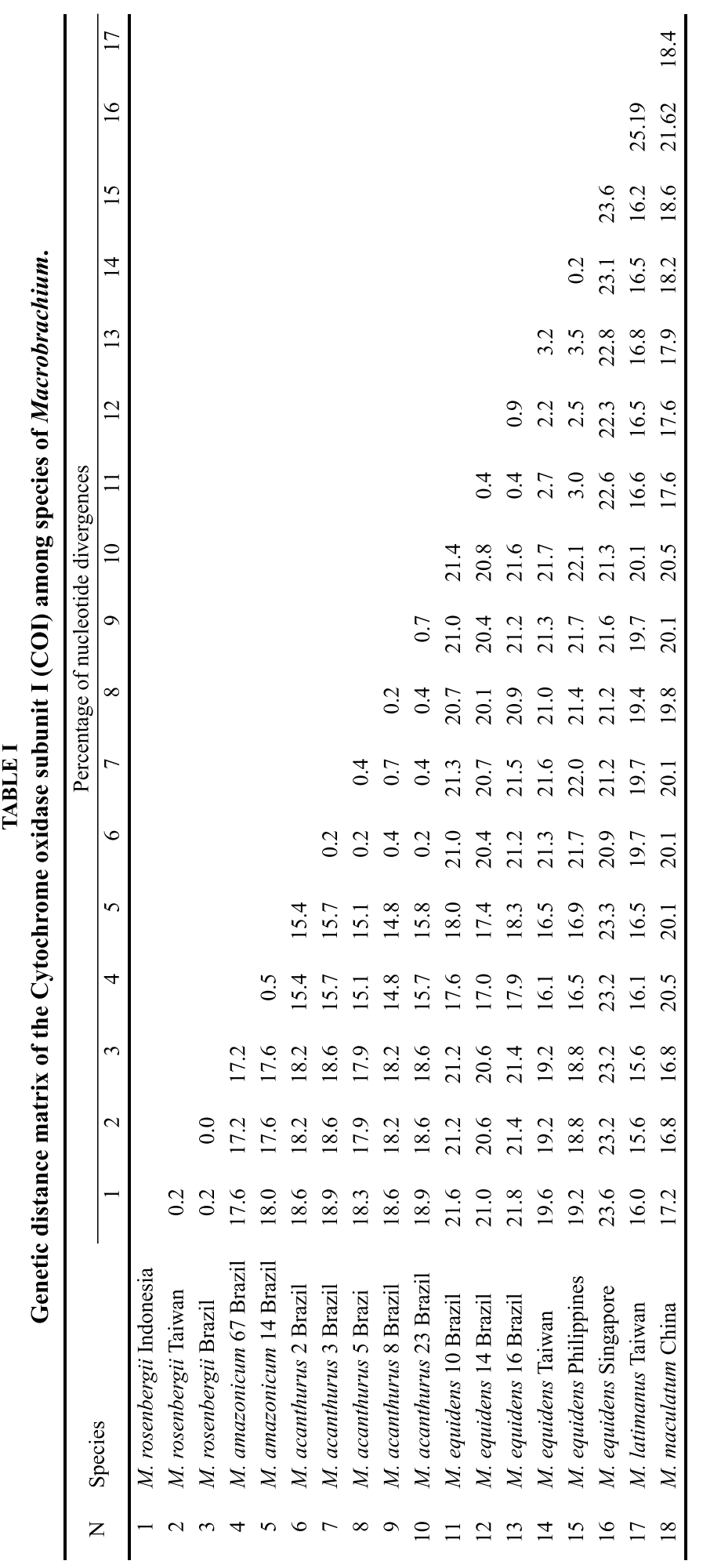




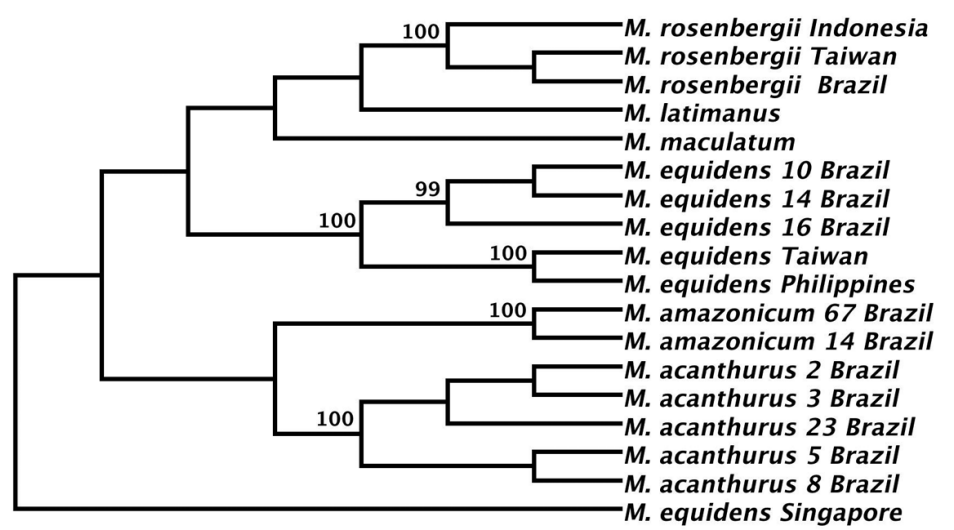

Fig. 2 - Unrooted phylogenetic tree constructed by the Neighbor-joining method obtained from sequences of the COI mitochondrial gene. The values at the nodes are bootstrap percentages for 1000 pseudoreplicates.

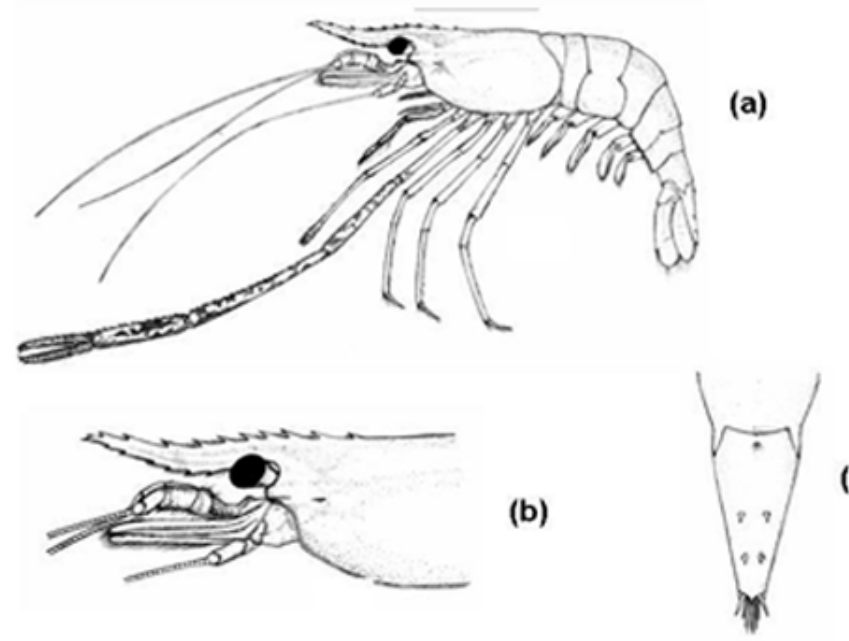

(c)
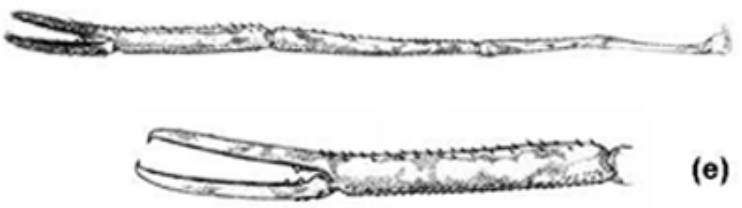

(e)

Fig. 3 - Macrobrachium equidens. (a) holotype (male), lateral view; (b) anterior region of the cephalothorax, lateral view; (c) chela (scale 11.4 $\mathrm{mm}$ ); (d) chela (scale 6.6mm); (e) telson (scale $10 \mathrm{~mm}$ ).

pereiopods are marbled with large areas of irregular, distinct orange-brownish staining, with smaller areas of red-brown and light yellow-brown; the articulations of the last 3 pereiopods present reddish staining.

\section{DISTRIBUTION}

Macrobrachium equidens is native of the Indo-Pacific Region (Short 2004), although it has also been recorded as an exotic species in West Africa (Powell 1986). This is the first known record of the species on the Atlantic coast of South America.

\section{REPRODUCTIVE BIOLOGY OF THE}

BRAZILIAN $M$. equidens

The Taici Creek is affected by the tidal flow, with salinity varying throughout the year, ranging from 1 in July (late wet season) to 25 in January (early wet season). Water temperature varied from 25 to $30^{\circ} \mathrm{C}$. Water tem- 
perature and salinity as well as meteorological data are shown in Figure 4. The $\mathrm{pH}$ level varied from 7.0 to 7.8. The lowest values for both $\mathrm{pH}$ and temperature were recorded during the period of greatest precipitation, while the highest $\mathrm{pH}$ values coincide with the months when salinity was over 10, except for March, when salinity was 11 , and $\mathrm{pH}=7.1$.

A total of 819 individuals was collected over the study period, of which 512 were identified as Macrobrachium amazonicum, 170 as M. equidens and 137 as M. acanthurus. All three species were captured throughout the year (Fig. 5), although the biological data presented here are for $M$. equidens only.

The weights of male and female $M$. equidens were statistically similar (males: mean $=2.64 \pm 0.24 \mathrm{~g}$, range $0.45-5.8 \mathrm{~g}, \mathrm{n}=48$; females: mean $=2.58 \pm 0.10 \mathrm{~g}$, range 0.6-6.23 g, $\mathrm{n}=122$ ), as were body lengths (males: mean $=55.55 \pm 13.08 \mathrm{~mm}$; females $=56.97 \pm 8.59 \mathrm{~mm}$ ). The sex ratio was $1: 2.55$, although the predominance of females was statistically significant only in the months of October and November (Table II). Overall, almost three-quarters $(73.91 \%)$ of females were egg-bearing (Fig. 6). These females were observed throughout the year, but were relatively more common in the dry season months of October and November. In the fecundity tests, females averaged 1,789.15 \pm 790.76 eggs, with a maximum of 3,702. Body size (TL) and the number of eggs were significantly correlated $(\mathrm{rs}=0.73 ; \mathrm{p}<$ $0.0001 ; \mathrm{n}=32$ ). The number of larvae per spawn correlated significantly ( $\mathrm{rs}=0.66 ; \mathrm{p}<0.0004 ; \mathrm{n}=24)$ with body size (TL), reaching a maximum of 4,027 larvae (mean $=1,181.70 \pm 1,269.03)$.

\section{DISCUSSION}

This study provides the first known report of the occurrence of Macrobrachium equidens, a species native of the Indo-Pacific Region, on the Amazon coast of Brazil. The identification of the species were confirmed by the COI mitochondrial gene. In addition, the fact that the species accounted for $20 \%$ of the specimens in the samples of Macrobrachium collected over the year indicates that the local population of $M$. equidens is well established. Powell (1986) reported the occurrence of $M$. equidens for the first time in Nigeria (eastern Atlantic) in 1982, and that the species had become established
TABLE II

Number of males and females M. equidens collected each month (no males were collected from July onwards) and values of Chi-square for the deviation of the sex ratio from 1:1 (1 degree of freedom).

\begin{tabular}{c|c|c|c|c}
\hline Month & Male & Female & $\begin{array}{c}\text { Sex ratio } \\
\text { (M:F) }\end{array}$ & Chi-square \\
\hline Oct/01 & 5 & 25 & $1: 5.0$ & $13.33^{*}$ \\
Nov/01 & 14 & 35 & $1: 2.5$ & $9.00^{*}$ \\
Dec/01 & 4 & 8 & $1: 2.0$ & 1.33 \\
Jan/02 & 3 & 10 & $1: 3.3$ & 3.77 \\
Feb/02 & 3 & 4 & $1: 1.3$ & 0.14 \\
Mar/02 & 11 & 13 & $1: 1.2$ & 0.17 \\
Apr/02 & 3 & 5 & $1: 1.6$ & 0.50 \\
May/02 & 4 & 8 & $1: 2.0$ & 1.33 \\
Jun/02 & 1 & 1 & $1: 1.0$ & 0 \\
\hline
\end{tabular}

in the rivers and estuaries of this country in only four years. This author suggests that the species arrived in the country via the discharge of ship's ballast.

The specimens of $M$. equidens analyzed in the present study are morphologically similar to those from Australia (Short 2004), Philippines (Cai and Shokita 2006) and India (Krishna-Murthy et al. 1987). In regarding to some congeners from the estuary of the Caeté River (Brazil), M. equidens can be distinguished by the presence of a pappose setal pubescence covering both dactyls of the second pereiopod (Fig. 3). This trait is also present in $M$. acanthurus, which hampers the diagnosis of both species. However, the rostrum of $M$. equidens presents three proximal teeth behind the orbit, whereas $M$. acanthurus has only two postorbital teeth, although some specimens of $M$. equidens present only two postorbital teeth, which demands the use of other criteria to distinguish the two species. The second pereiopod of $M$. equidens is narrower than that of $M$. acanthurus, and has chelae with two well-defined proximal teeth in the dactyl and another one in the fixed finger followed by three basal denticles. By contrast, $M$. acanthurus has only one distinct tooth in the proximal portion of the dactyl and four denticles between them and the finger base in the fixed finger. M. equidens also presents distinct orange-brownish staining in all the articulations, whereas the articulations of the pereiopod of $M$. acanthurus are greenish in color. M. equidens may also be confused with $M$. amazonicum, although two characteristics clearly differentiate the two species: 

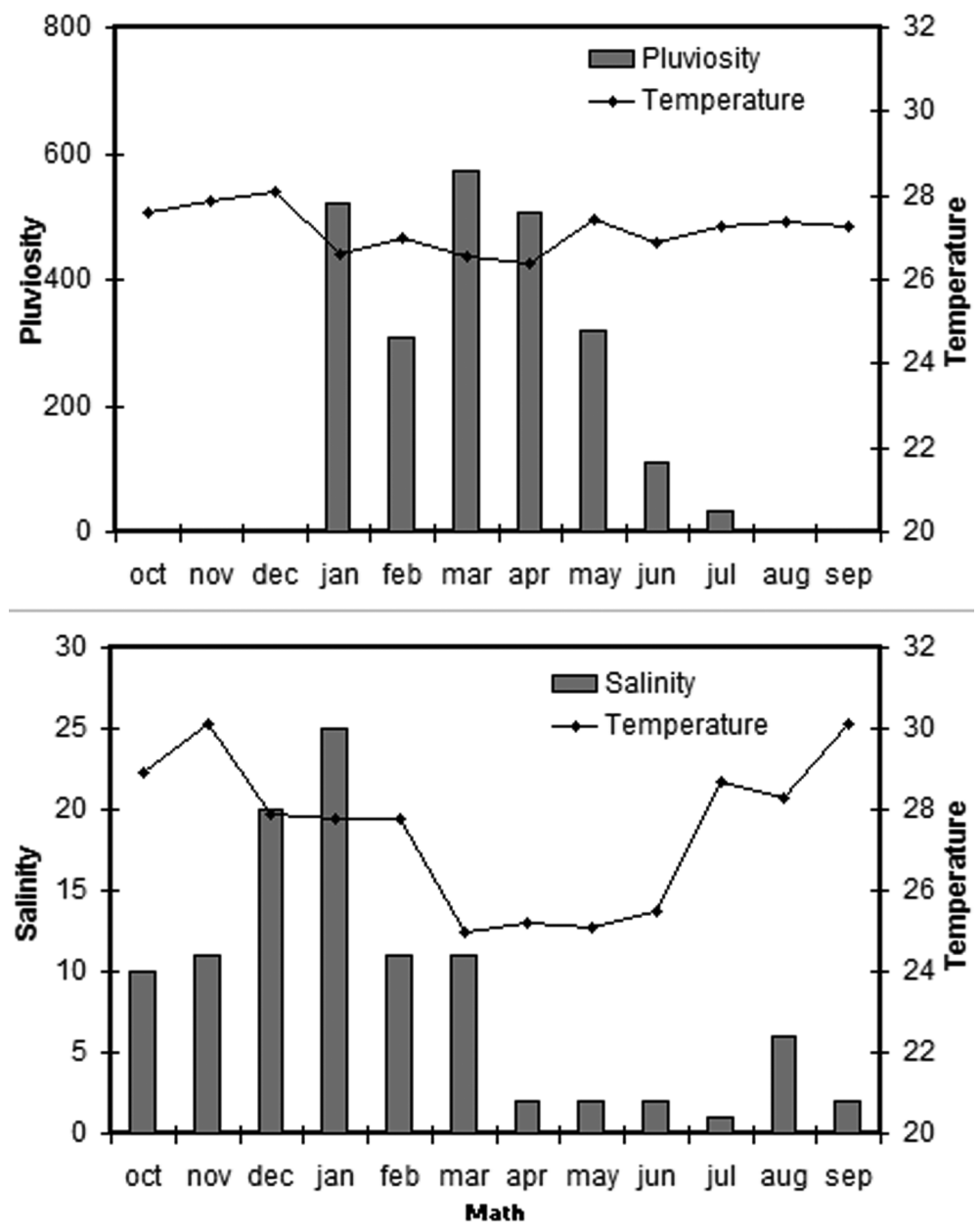

Fig. 4 - Monthly precipitation and average air temperature (above) and salinity and water temperature (below) recorded each month in the Caeté Estuary between October 2001 and September 2002.

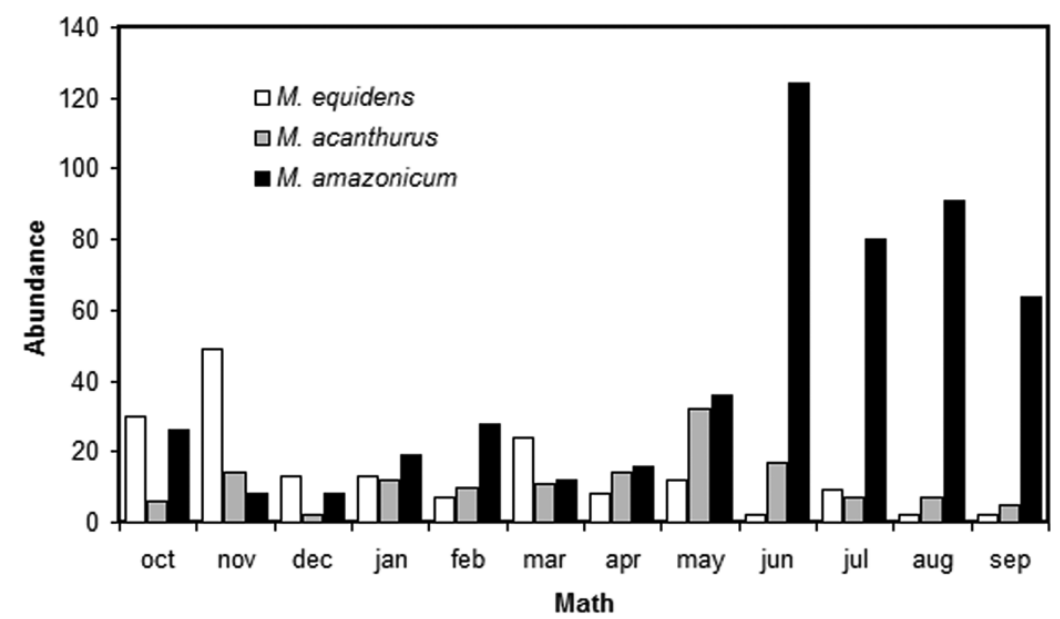

Fig. 5 - Number of specimens of different Macrobrachium species captured in the Caeté Estuary between October 2001 and September 2002. 


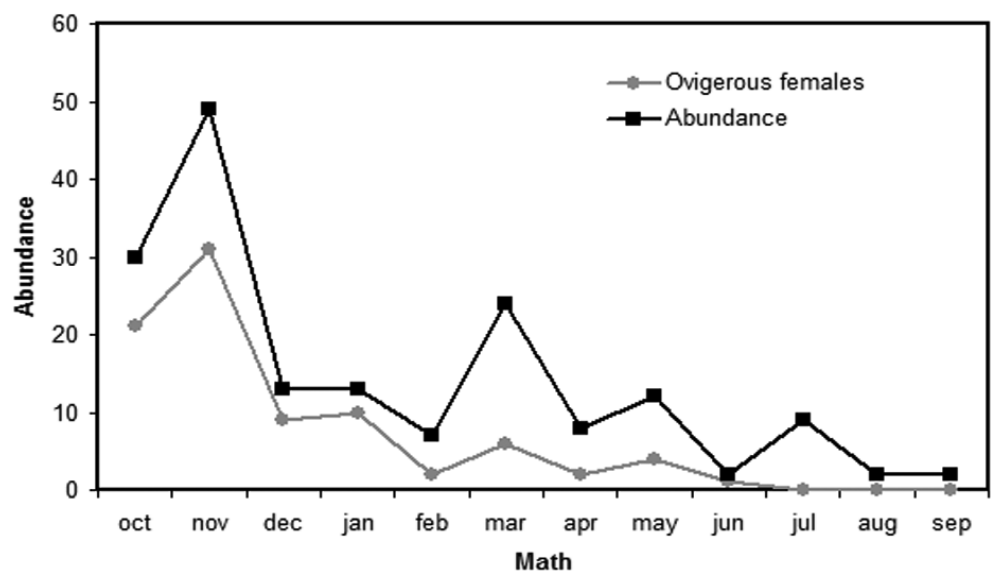

Fig. 6-Overall abundance and number of ovigerous females of Macrobrachium equidens collected each month in the Caeté Estuary between October 2001 and September 2002.

M. amazonicum presents an elongated rostrum, with dorsal teeth well spaced at the extremity, in addition to a telson with a sharp and narrow tip, covered with very short spines that do not extend beyond this structure, whereas M. equidens has a rostrum the same length as, or longer than the scaphocerite, and a telson with long spines covered with bristles, which extend beyond its tip.

The analysis of the mitochondrial COI gene was the main key to confirm the species status of $M$. equidens, which indicates close genetic similarity with specimens from Taiwan and the Philippines. Our analysis reconfirmed the high nucleotide divergence (22-23\%) between these specimens and $M$. equidens from Singapore, as reported by Liu et al. (2007), who suggests that this might be a case of cryptic species.

The results of the present study indicate unequivocally that the $M$. equidens stocks introduced into Brazil were from the Indo-West Pacific Region (Taiwan or the Philippines), based on the comparison against approximately 300 COI sequences from Genbank, representing dozens of Macrobrachium species. However, the relatively high genetic divergence (approximately 3\%) between the Brazilian and Asian populations of $M$. equidens appears to contradict the hypothesis that the species was introduced recently from ballast water discharges or accidentally together with other exotic species for aquaculture purposes, such as Macrobrachium rosenbergii, which was brought to Brazil in the nineteen-seventies (Cavalcanti 1998). One possibility - that requires closer attention - is that the Amazonian pop- ulation of $M$. equidens in the western Atlantic was derived from Nigerian stocks in the eastern Atlantic (Powell 1986) through the migration of larvae on ocean currents. We recently recorded similar levels of divergence of COI between Brazilian and west African populations of Octopus vulgaris, which suggest similar mechanisms of larval dispersal (J.B.L. Sales et al., unpublished data).

The relative abundance of the species in the study area suggests that the species is well established, with a high probability of permanent colonization. We recently collected juveniles of this species (G. Iketani et al., unpublished data) on another river of the Amazon coast, Patal River, in the municipality of Augusto Corrêa $\left(01^{\circ} 04^{\prime} 29.1^{\prime \prime} \mathrm{S}, 46^{\circ} 38^{\prime} 8.7^{\prime \prime} \mathrm{W}\right)$. The species is tolerant to a considerable variation in salinity, ranging from freshwater to 40, and is classified as a hyper- and hypoosmotic regulator (Denne 1968). Larval development may also occur in ocean water (Ngoc-Ho 1976). In addition, $M$. equidens is able to inhabit rivers and estuaries, as well as to tolerate areas under major anthropogenic impact (Short 2004). Altogether, then, the species appears to be more than able to adapt to new environments. In addition, it is normally carnivorous (Krishna-Murthy and Rajagopal 1990) and, as a predator, it may have a considerable impact on native species.

Macrobrachium equidens was collected in the Caeté Estuary throughout the year. The abundance and reproductive condition of the species appeared to be influenced by salinity and precipitation, whereas little variation in $\mathrm{pH}$ or temperature was recorded during the study 
period. The species was most abundant during the dry season, between January and June, whereas salinity peaked in December (20) and January (25). Few individuals and no ovigerous females were collected at the beginning of the dry season (July to September) when salinity was less than 6 . Interestingly, M. amazonicum figured prominently in the captures during these months (Fig. 5), which may partly account for the reduced numbers of M. equidens and M. acanthurus in the traps, as a result of competition. The relative abundance of $M$. equidens throughout the year and continuous breeding were also recorded in parts of India, within the natural range of the species (Krishna-Murthy et al. 1987). The specimens collected in the Caeté Estuary - both males and females - were also similar in size (CL and TL) to animals from natural populations in Australia (Short 2004), the Philippines (Cai and Shokita 2006) and India (Krishna-Murthy et al. 1987).

Palaemonid shrimps present a variety of reproductive strategies, which are influenced by environmental factors (Magalhães and Walker 1988, Odinetz-Collart and Magalhães 1994, Jalihal et al. 1993). A concentration of breeding during the rainy season has been recorded in populations of M. acanthurus in Bahia and São Paulo, in northeastern and southeastern Brazil, respectively (Carvalho et al. 1979, Carvalho 1983, Valenti et al. 1986), as well as in species such as Macrobrachium borellii (Bond and Buckup 1982), Macrobrachium potiuna (Bond and Buckup 1982, Antunes and Oshiro 2004), M. amazonicum (Odinetz-Collart 1991) and Macrobrachium olfersi (Mossolin and Bueno 2002). On the other hand, Lobão et al. (1978) recorded a reduction in the number of ovigerous females of $M$. holthuisi during the rainy period. A similar pattern was observed in the present study - ovigerous females of M. equidens were most abundant at the end of the dry season (salinity 10-11). However, reproductive behavior was observed in almost every month, which possibly represents a strategy to compensate for reduced fertility.

Fertility in M. equidens from the Caeté Estuary $(1,181 \pm 1,269$ larvae, with a maximum of 4,027$)$ was similar to fecundity $(1,789.15 \pm 790.76$ eggs $)$. Studies in India, within the species' natural range, recorded fertility of between 448 and 8,281 eggs per female, with a mean of 2,752 (Krishna-Murthy et al. 1987). While this average is similar to that recorded in the present study, the maximum value is considerably higher. This difference may reflect a process of adaptation of the species to the Amazon coast. However, in comparison with native species, while the mean fertility and fecundity of M. equidens were lower than those of M. acanthurus (Valenti et al. 1989), fecundity was similar to that recorded for M. amazonicum, a species with a good potential for aquaculture (Kutty et al. 2000).

The sex ratio of $M$. equidens was 1:2.55, although the predominance of females was significant only in the dry season months of October and November. While a similar skew in the sex ratio was not observed in India (Krishna-Murthy et al. 1987), the proportion of females did increase during the months of increased reproductive activity, which is a pattern similar to that observed in the present study. A high proportion of females to males during the reproductive period has also been observed in M. amazonicum from the Tocantins River in the Brazilian state of Pará (Odinetz-Collart 1987, 1991, Silva et al. 2005).

Macrobrachium equidens is currently known to occur in Brazil only at the present study site on the eastern Amazon coast, although further studies are required to verify the extent of its distribution along the northern coast of Brazil. The location of this region would nevertheless be consistent with the hypothesis that this population has been established as a result of the transportation of larvae from Nigeria via the South Equatorial Current. The species' tolerance to an ample range of salinity contributes to its capacity for dispersal and colonization of new areas, while its relative abundance and reproductive potential may help to establish an endemic population and promote its expansion into new areas. Obviously, then, further studies are required in order to evaluate the effects of this invasive form on native species and ecosystems.

\section{ACKNOWLEDGMENTS}

We thank Stephen F. Ferrari for his valuable suggestions. This study was financed by Conselho Nacional de Desenvolvimento Científico Tecnológico (CNPQ/ PADCT-MCT) (Millennium Institute Project) and Fundo Estadual de Ciência e Tecnologia do Pará (FUNTEC-PA). 


\section{RESUMO}

O camarão de água doce Macrobrachium equidens, nativo da região do Indo-Pacífico, foi registrada pela primeira vez na costa da Amazônia Brasileira. Esta espécie foi encontrada habitando o mesmo ambiente que duas espécies nativas do gênero Macrobrachium: M. amazonicum e M. acanthurus, e é morfologicamente muito similar à última. A identificação dessa espécie foi confirmada pela análise da seqüência genética do gene mitocondrial Citocromo Oxidase (COI). Uma descrição detalhada das características morfológicas e biologia reprodutiva de $M$. equidens neste novo ambiente é apresentada.

Palavras-chave: crustáceos, Estuário do Caeté, espécies invasivas, gene mitocondrial COI, biologia reprodutiva.

\section{REFERENCES}

Antunes LS AND OSHIRo LMY. 2004. Aspectos reprodutivos do camarão de água doce Macrobrachium potiuna (Müller) (Crustacea, Decapoda, Palaemonidae) na Serra do Piloto, Mangaratiba, Rio de Janeiro, Brasil. Rev Bras Zool 21(2): 261-266.

Barros MP And Pimentel FR. 2001. Decapoda (Crustacea) do estado do Pará, Brasil: lista preliminar das espécies. Bol Mus Para Emílio Goeldi, ser Zool 17(1): 15-41.

BOND G AND BuCKUP L. 1982. O ciclo reprodutor de Macrobrachium borellii (Nobili, 1896) e Macrobrachium potiuna (Muller, 1880) (Crustacea, Decapoda, Palaemonidae) e suas relações com a temperatura. Rev Brasil Biol 42(3): 473-483.

Bond-Buckup G AND Buckup L. 1989. Os Palaemonidae de águas continentais do Brasil meridional (Crustacea: Decapoda). Rev Bras Zool 49(4): 883-896.

CAI Y AND SHOKITA S. 2006. Reporto on a collection of freshwater shrimps (Crustacea: Decapoda: Caridea) from the Philippines, with descriptions of four new species. Raffles Bull Zool 54(2): 245-270.

CARvalho HA. 1983. Reprodução do Pitu Macrobrachium acanthurus (Wiegmann, 1836). Subsídio às atividades de cultivo. I. Influência da temperatura. Bol Fisiol Animal 7: $95-101$.

CARvalho HA, Gomes MGS, Gondim AQ ANd PEREIRA MCG. 1979. Sobre a biologia do pitu - Macrobrachium acanthurus (Wiegmann, 1836) em populações naturais da Ilha de Itaparica. Universitas 24: 25-45.

Cavalcanti LB. 1998. Histórico, p. 17-20. In: Valenti WC. Carcinicultura de água doce tecnologia para produção de camarões. Brasília, 393 p.
Coelho PA AND RAmos-Porto M. 1985. Os camarões da água doce do Brasil: distribuição geográfica. Rev Bras Zool 2(6): 405-410 (in Portuguese with English abstract).

DENNE LB. 1968. Some aspects of osmotic and ionic regulation in the prawns Macrobrachium australiense (Holthuis) and M. equidens (Dana). Comp Biochem Physiol 26: 1730 .

HALL TA. 1999. BioEdit: a user-friendly biological sequence alignment editor and analysis program for Windows 95/98/NT. Nucl Acids Symp Ser 41: 95-98.

Holthuis LB. 1951. A general revision of the Palaemonidae (Crustacea Decapoda Natantia) of the Americas. I. The Subfamily Euryrhynchinae and Pontoniinae. Allan Hancock Occas Pap 11: 1-332.

Holthuis LB. 1952. A general revision of the Palaemonidae (Crustacea, Decapoda, Natantia) of the Americas. II. The Subfamily Palaemonidae. Allan Hancock Occas Pap 12: $1-396$.

Jalihal DR, SAnkolli KN And Shakuntala Shenoy S. 1993. Evolution of larval developmental patterns and the process of freshwaterization in the prawn genus Macrobrachium Bate, 1968 (Decapoda, Palaemonidae). Crustaceana 65(3): 365-376.

Kensley B AND WalKer I. 1982. Palaemonid shrimps from the Amazon Basin, Brazil. (Crustacea, Decapoda, Natantia). Smithson Contrib Zool 362: 1-28.

KIMURA M. 1980. A simple method of estimating evolutionary rates of base substitutions through comparative studies of nucleotide sequences. J Mol Evol 16: 111-120.

KrishnA-Murthy D And Rajagopal KV. 1990. Food and feeding habits of the freshwater prawn Macrobrachium equidens (Dana). Indian J Anim Sci 60(1): 118122.

Krishna-Murthy D, Rajagopal KV, VArghese TJ AND UDUPA KS. 1987. Reproductive biology of the freshwater praw Macrobrachium equidens (Dana). Indian J Anim Sci 57(9): 1026-1034.

Kutty MN, Herman F AND MenN HL. 2000. Culture of others species, p. 393-410. In: New MB and Valenti WC (Eds), Freshwater prawn farming: the farming of Macrobrachium rosenbergii. Oxford. Blackwell Science, $443 \mathrm{p}$.

LIU MY, CAI YX AND TZENG CS. 2007. Molecular systematics of the freshwater prawn genus Macrobrachium bate, 1868 (crustacea: decapoda: palaemonidae) inferred from mtDNA sequences, with emphasis on east asian species. Zool Stud 45(3): 272-289.

LobÃo VL, SAWAYA P AND SANTOS LE. 1978. Influência da temperatura, precipitação pluviométrica e insolação 
na reprodução de Macrobrachium holthuisi. Genofre and Lobão, 1976 (Crustácea, Decapoda). Bol Inst de Pesca 5(2): 109-118. (in Portuguese with English abstract).

Magalhães C, Bueno SL, Bond-Buckup G, VAlenti WC, Silva HLM, KiYohara F, Mossolin EC AND Rocha SS. 2005. Exotic species of freshwater decapod crustaceans in the state of São Paulo, Brazil: records and possible causes of their introduction. Biodivers Conserv 14: 1929-1945.

Magalhães C AND WALKER I. 1988. Larval development and ecological distribution of central Amazonian palaemonid shrimps (Decapoda, Caridae). Crustaceana 5(3): 279-292.

Melo GAS. 2003. Manual de identificação dos Crustacea Decapoda de água doce do Brasil. São Paulo. Edições Loyola, 429 p. (in Portuguese).

Miller AD, Murphy NP, Burridge CP And Austin CM. 2005. Complete Mitochondrial DNA Sequences of the Decapod Crustaceans Pseudocarcinus gigas (Menippidae) and Macrobrachium rosenbergii (Palaemonidae). Mar Biotechnol 7: 339-349.

Mossolin EC AND Bueno SL. 2002. Reproductive biology of Macrobrachium olfersi (Decapoda, Palaemonidae) in São Sebastião, Brazil. J Crust Biol 22(2): 367-376.

NGOC-Ho N. 1976. The larval development of the prawns Macrobrachium equidens and Macrobrachium sp. (Decapoda: Palaemonidae), reared in the laboratory. J Zoo Lond 178: 15-55.

Odinetz-Collart O. 1987. La pêche crevettière de $M a$ crobrachium amazonicum (Palaemonidae) dans le BasTocantins après la fermeture du barrage de Tucurui (Brésil). Rev Hydrobiol Trop 20(2): 131-144.

Odinetz-Collart O. 1991. Tucurí dam and the populations of the prawn Macrobrachium amazonicum in the lower Tocantins (PA - Brazil): a four year study. Arch Hydrobiol 122(2): 213-227.

Odinetz-Collart O And Magalhães C. 1994. Ecological constraints and life history strategies of palaemonid prawns in Amazonia. Verh Internat Verein Liminol 25: 2460-2467.
PALUMBi SR AND BenZIE J. 1991. Large mitochondrial DNA diferences between morfologically similar Penaeid shrimp. Mol Mar Biol Biotechnol 1: 27-34.

Powell CB. 1986. Occurrence of the Indo-Pacific prawn Macrobrachium equidens in West Africa (Crustacea, Decapoda, Palaemonidae). Rev Hydrobiol Trop 19(2): 7579.

Ramos-Porto M. 1979. Pseudopalaemon amazonensis, espécie nova de camarão da bacia amazônica (Crustacea, Decapoda, Palaemonidae). Cienc Cult 31(7): 693.

Ramos-Porto M ANd Coelho PA. 1990. Sinopse dos crustáceos decápodos brasileiros (Família Palaemonidae). Anais Soc Nord Zool 3: 93-111. (in Portuguese with English abstract).

ShorT JW. 2004. A revision of Australian river prawns, Macrobrachium (Crustacea: Decapoda: Palaemonidae). Hydrobiologia 525: 1-100.

Silva KCA, Cintra IHA AND Muniz APM. 2005. Aspectos bioecologicos de Macrobrachium amazonicum (Heller, 1862) a jusante do reservatório da hidrelétrica de Tucuruí, Pará. Bol Tec Cient Cepnor 5(1): 55-71.

Tamura K, Dudley J, Nei M and Kumar S. 2007. MEGA4: Molecular Evolutionary Genetics Analysis (MEGA) software version 4.0. Mol Biol Evol 24: 15961599.

TANABE AS. 2007. Kakusan: a computer program to automate the selection of a nucleotide substitution model and the configuration of a mixed model on multilocus data. Mol Ecol Notes 7: 962-964.

Valenti WC, Mello JTC and Lobão VL. 1986. Dinâmica da reprodução de Macrobrachium acanthurus (Wiegmann, 1836) e Macrobrachium carcinus (Linnaeus, 1758) do Rio Ribeira de Iguape (Crustacea, Decapoda, Palaemonidae). Cienc Cult 38(7): 1256-1262. (in Portuguese with English abstract).

VAlenti WC, Mello JTC And Lobão VL. 1989. Fecundidade em Macrobrachium acanthurus (Wiegmann, 1836) do Rio Ribeira de Iguape (Crustacea, Decapoda, Palaemonidae). Rev Bras Zoo 6(1): 9-15. 